\title{
BASIC PRINCIPLES OF PRAXEOLOGICAL COMPETENCE FORMATION IN FUTURE MASTERS OF DENTISTRY
}

\author{
Ya. Kulbashna, I. Skrypnyk
}

The problem of definition of key principles of forming the praxeological competence of a future specialist in the system of higher medical, especially dentistry, education, is considered, based on the analysis of the international experience, especially one of countries-participants of the Bolognese process that the Ukrainian system of higher education continues to integrate in, and contributions of native scientists-teachers. It is underlined, that modernization of the educational process at globalization and migration of the planet population needs constant renewal and optimization of its theoretical grounds, based on the competence approach for providing specialists' employment. An important place in this process belongs to the definition of basic functioning principles of all development elements of the education system, especially practical training. Attention is paid on the importance of observance of both legally accepted development principles of the education system, students' civic rights and ones, providing its innovativeness and social demands.

The retrospective analysis of the development of "praxeology" science and views of modern scientists on introduction of the praxeological approach and its importance for increasing the quality of practical training of graduates of higher medical educational institutions has been conducted.

It is determined, that one of main components of the effective practical training of future dentistry masters at higher medical educational institutions is praxeological competence formation that provides further high-quality professional activity in the sphere of not only manual skills, but also determination of optimal organizational forms, methods, selection of materials in the professional activity of a physician-dentist.

Based on the analysis of scientific sources and own studies, there have been concretized main principles of praxeological competence formation in dentistry masters, namely: successiveness, transparency, provability, scientism, rationality, creativity, efficiency

Keywords: medical education, practical training of dentistry masters, principles of praxeological competence formation

Copyright (C) 2020, I. Skrypnyk, Ya. Kulbashna.

This is an open access article under the CC BY license (http://creativecommons.org/licenses/by/4.0).

\section{Introduction}

The modern system of higher education both in Ukraine and abroad continues reforming, based on the competence approach (below - CA). Since the beginning of 21 century, the united European educational and scientific space (UEESS) has been created [1], and Ukraine is striving to integrate into it. Within it there are proclaimed common approaches to learning, employment, mobility of future specialists that favors the increase of competitiveness of graduates at the labor market. Scientists pay the special attention to the elaboration of theoretical bases of the educational process at higher school, determining both general principles of its establishing and functioning [2, 3], and its correspondent components, especially practical training [4].

One of basic components and final sense of introducing CA in higher education is defined as the ability of a graduate of higher educational institutions (below-HEI) to realize acquired knowledge in the professional activity [4]. The importance of the readiness of a medical HEI graduate to the practical activity is accented in the Strategy of higher medical education reformation [5], because interrogations of students of native medical universities as to the correspondence of their practical training to requirements of the branch educational standard, labor market fixed an anxious tendency to essential decrease. The analysis of scientific sources proves that both native and foreign scientists $[4,6]$ indicate an insufficient level of practical training of future scientists and professional competence formation of HEI graduates. So, the increase of their level becomes an important task of higher school. In the context of $\mathrm{CA}$ it is provided by the complex of correspondent competences [7], must be acquired by a graduate in the process of professional training, which form his/her professional competence by integration.

One of special physician's competences is determined as praxeological [4] that comprehensively covers all aspects and provides an effective realization and organization of the practical activity. Modern market requirements to the high-quality practical training of a HEI graduate, especially medical one, actualize the necessity to concretize basic principles of its formation as an essential component of the theoretical base of the future physician's professional training.

\section{Literary review}

Already in classic European universities, scientists paid attention to the problem of organization and increase of the practical work efficiency. Theoretical contributions, directed on the effective support of the 
specialists' practical activity in general, basic aspects resulted (in 18 century) in a new direction "praxeology", which main principles were formulated by the French philosopher A. Espinas and Ukrainian economistmathematician E. Slutsky, and the content of the correspondent discipline at educational institutions was given by T. Kotarbinsky and T. Psholovsky $[8,9]$. Not only manual, but general approaches to the complex process of organization, support and realization of the professional activity are considered in the format of praxeology. In the middle of 20 century the unsatisfactory condition of the practical training of higher educational institutions graduates by assessments of employers favored scientists to elaborate and to introduce the competence approach in higher education [4].

In the modern native pedagogical theory, praxeological bases and approaches in different fields of higher education, were developed by V. Maiboroda, V. Artemov [4], V. Polischuk [10] and other, their introduction, taking into account the importance of perfect practical training of a physician for a patient, is observed also in medical education $[4,8]$. Its modern model [11] that provides harmonization of a training program of future dentistry masters with the branch educational Standard (2019) and requirements of the World Federation has been elaborated in the native educational space for increasing the level of practical training. It provides step-be-step improvement of practical abilities and skills, mastered at the sixth practically oriented year of study.

The analysis of scientific sources on the problem of increasing the efficiency of the medical HEI graduate's practical training indicates that in elaboration of theoretical bases that provide different components and stages of the educational process, especially formation of special competences, the special place is occupied by the necessity to establish a system of basic requirements, guiding positions, theoretically substantiated and practically confirmed, outlined in scientific-pedagogical sources by the notions "principles" [4].

At the beginning of studying the problem of definition of formation principles of the praxeological competence of future dentistry masters, we pay attention to the fact that the State legally accepted in the Law of Ukraine "On education" (art.6) [2] the main principle of native education - "Education in Ukraine must be built by the principle of equal possibilities for all", on such Bases: accessibility of all forms and types of educational services, given by the state for each citizen; equal conditions of each person for complete realization of his/her abilities, talents, comprehensive development; humanism, democracy, priority of spiritual values, common to mankind; organic connection with the world and national history, culture, traditions; independence of education from political parties, public and religious organizations; scientific, secular character of education; integration with science and production; interconnection with education of other countries; flexibility and prognostication; combination of state management and public self-government in education.

At the same time the Law of Ukraine "On higher education" [12] proclaims basic principles of its functioning, correlating with ones, declared in the "Law on education" [2]. Let's accent ones of them, which topicali- ty is extremely important in the epoch of globalization and which, undoubtedly, regulate the process of practical training of higher education applicants, especially: promotion of the sustainable development of society by training the competitive human capital and creating conditions for lifelong education; international integration of the Ukrainian system of higher education into the European space of higher education at keeping and developing achievements and progressive traditions of the national higher school; state support of training specialists with higher education for priority branches of economic activity, directions of fundamental and applied scientific studies, scientific-pedagogic and pedagogic activity; state support of educational, scientific, scientifictechnical and innovative activity of universities, academies, institutes, colleges; promotion of realization of the state-private partnership in the sphere of higher education; open formation of the structure and volume of the educational and professional training of specialists with higher education.

At the same time while integrating to the international educational space, the native educational community must take into account international acts, regulating higher education system functioning abroad. Thus, EU proclaimed in the Bolognese declaration (2003) [7], joined by Ukraine in 2005, basic principles of the Bolognese process. They have the democratic and integrating character for all countries-signers, especially:

- introduction of two-cycle learning: pregraduate and postgraduate;

- control over education quality that is planned to be realized by accreditation agencies, independent from national governments and international organizations;

- widening of HEI students', staff's and teachers' mobility for mutual enrichment with the European experience;

- guaranteeing of graduates' employment at the expanse of acceptance of professional qualifications, identified by the "Addition" to a diploma;

- creation of an attractive European educational system for engaging more students from different regions of the world to Europe.

At the same time for increasing the higher education quality in European countries after introducing the competence approach, attention was concentrated on elaboration of higher education functioning principles in the format of knowledge "triangle":

- innovativeness;

- continuous professional development (CPD);

- learning through researching $\bullet$ academic mobility [4].

In the context of the aforesaid it must be accented, that the definition of the following principles of innovative development of native education by Sisoeva became especially important for native medical education that train future specialists, based on the advanced world experience and innovative achievements of practice and science:

- priority of the human personality and its development;

- fundamentality and continuity;

- replacement of the knowledge education paradigm by the competence one; 
- acceptance of multiculturalism and tolerance in the intercultural environment;

- convergence and globalization; directionality on providing the sustainable civilization development;

- introduction of informational technologies [4].

Active processes of deepening and modernization of the theoretical base of higher education according to the modern requirements can be observed in the world educational space. Thus, the Council of international schools, counting more than 1360 higher educational institutions from 122 countries and supporting highest standards of ethic practice and professional behavior at admission of students to higher educational institutions, has developed the "Higher education principles", covering several actual directions in the system of higher education, especially in the spheres of "Publications", "Marketing and promotion of graduates", "Non-discrimination", "Institutional policy and programs" [3].

We find the experience of foreign scientists, who formulated basic principles for increasing the efficiency of students' practical training at the pregraduate stage [13], namely:

- encouragement of contracts between students and teachers; - development of interaction and cooperation among students;

- stimulation for active learning;

- timely reaction on students' demands;

- concentration on terms of task performance;

- support of ambitious expectations; - respect to diverse talents and learning means and so on, extremely urgent for the research topic.

In democratic countries in general and particularly in the international educational space, the great importance is given to protection of human rights and freedoms of students in higher education that correspondent principles, elaborated in cooperation by members of the Highest coalition on civic rights in 2018 were determined for [14]. Let's cite those of them, considered especially urgent for the system of native education, namely:

- support of student's civic rights, defined by law; admission;

- access to education by eliminating obstacles for

- promotion of persistence in learning and completion of higher education acquisition;

- accessibility for each one, especially persons with low income levels;

- collection, processing, generalization of comprehensive data about higher education, reporting about them;

- refusal of financing educational institutions, not demonstrated their importance for students and so on.

Even in times of social disorders and uncertainty, disorganizing all processes, including educational ones, foreign scientists find it necessary to concentrate on the following key principles of higher education $[15,16]$ :

- to share own best practical achievements;

- to keep close contacts with students;

- to concentrate on the competence formation of future specialists.

Its modern model [10] that provides harmonization of a training program of future dentistry masters with the branch educational Standard (2019) and requirements of the World Federation has been elaborated in the native educational space for increasing the level of practical training. It provides step-be-step improvement of practical abilities and skills, mastered at the sixth practically oriented year of study.

Actualization of the problem of training a competent physician in medical HEIs caused a necessity to elaborate principles of future dentistry specialists' professional competence formation [4]:

- scientism and provability;

- prognostication;

- systemacy;

- anthropocentrism;

- advance in practice and theory of sciences;

- partnership - pedagogy of cooperation between teachers and students;

- successiveness;

- heuristics.

Despite the fact that the process of dentistry master's praxeological competence formation is an inseparable component of his/her professional competence [3], it has specific peculiarities and also needs definition of basic principles as one of its theoretical bases.

\section{Aim and tasks of research}

The research aim is to define basic principles of future dentistry master's praxeological competence formation.

The following tasks were set for attaining this aim:

1. To define guiding principles of higher education in the native and international educational space.

2. To separate ones, regulating the practical training and formation of correspondent competences in future specialists.

3. To elaborate formation principles of the dentistry master's praxeological competence.

\section{Materials and methods}

The following methods were used in the study: theoretical - analysis, systematization of data of native and foreign scientists as to the notion "principles", key principles of higher education in the legislative and scientific space of Ukraine and international acts. The studied problem was elaborated and own view of its solution was defined, conclusions were made; empirical - interrogation of future dentistry masters, observance of the educational process, investigation of the experience of other teachers of medical HEIs of Ukraine.

\section{Research results and their discussion}

For determining a satisfaction level of graduates of the National medical university, named after O.O. Bogomolets, (NMU) in the practical training (April of 2019), the interrogation was conducted (245 persons) and it was revealed that $40.0 \%$ of them are not satisfied, and $16.2 \%$ cannot answer this question. In 2020 the analogous research was also conducted, but we find comparisons with the obtained data not enough correct, because one of most responsible stages - the final one of the practical training - subtraineeship coincided with the quarantine, proclaimed in the state because of the Covid-19 pandemic. At the same time according to the interrogation results of the Association of students-dentists of Ukraine, presented at the Scientific-practical, reporting- 
elective conference of the Public Organization "Ukrainian Association of dentistry education" in honor of the hundred anniversary of the dentistry department of the NMU, named after O.O. Bogomolets (28 of November of 2019), the question "Are You satisfied with practical skills, acquired at clinical departments of the university?" was answered as "No" by $69 \%$, "Not sure" - by $16 \%$, "Yes" - by $15 \%$

For comparing, let's present the research data of 2014 in leading medical universities of Ukraine: NMU, Ternopil national medical university, named after $\mathrm{Y}$. Gorbachevsky, Vinnytsya national medical university, named after M.I. Pirogov, Ivano-Frankivsk medical university, where the low formation level of practical abilities and skills was noted by $29.7 \%, 16.5 \%, 23.8 \%$, $20.7 \%$, and the high one only by $18.7 \%, 15 \%, 24.1 \%$, $19.6 \%$ of respondents respectively [3].

The abovementioned data indicate that the problem of practical training of future dentistry masters at native medical HEIs still remains unsolved. The situation may be improved by the process of praxeological competence formation, which theoretical and methodological principles must be substantiated, especially basic ones.

The analysis of the normative-legal base and the international and foreign experience has revealed the data only about separate theoretical contribution of scientists in the research problem. The experience of pedagogical observations of scientists-teachers of medical HEIs and the own one gave a possibility to formulate the following principles of praxeological competence formation in future dentistry masters:

Successiveness - provides successive mastering of manipulations, corresponding to requirements of the branch Standards, from simple to complicated ones, understanding of urgency stages of aid provision and the necessity of its delay, choice of optimal organizational forms, conditions and methods.

Scientism - opens the necessity of observing the requirement to use only scientifically substantiated methods, materials, approaches, undergone the experimental provability, not harmful or with a minimal negative influence on the patients' organism in the practical activity. A future physician must know ways of access and use scientific sources broadly, obtain necessary modern information from them, analyze it for appropriateness to use, taking into account peculiarities of the human organism and observance of correspondent conditions.
Provability - is based on the necessity and ability to prove or to disprove professionally important information. For this aim, a future physician must master the methods of data analysis and synthesis, to acquire the ability to conduct a comparative characteristic in the context of a studied problem, to begin an experimental research within an accessible base and to interpret obtained results.

Transparency - provides formation of skills of maximally open discussion of all details of the treating process (choice of materials, methods and so on), taking into account possible negative influences on the human organism, development of complications, individual physical, mental, material peculiarities of a patient objectively, observing the patients' right for "second opinion", in a future physician.

Rationality - opens the necessity of searching a problem solution, optimal for a patient, especially at presence of several ones, - that particularly takes into account his/her physical status, anatomic and physiological peculiarities, material possibilities.

Creativity - provides elaboration, efficiency confirmation and use of original non-typical variants of solving clinical tasks and problems in the practical activity.

Efficiency - a result must restore a lost function, anatomical structure, to satisfy a patient esthetically and functionally as soon as possible.

\section{Conclusions}

1. Based on the analysis of the accessible scientific sources, the guiding principles of higher education in the native and foreign educational space have been defined.

2. It has been established, that the praxeological competence is one of special competences in the context of professional competences of future dentistry masters. Data about definition of its basic principles have not been revealed among theoretical aspects of the professional training and praxeological competence formation in future specialists, especially dentistry masters.

3 . There have been defined principles of praxeological competence formation in dentistry masters, namely: successiveness, transparency, provability, scientism, rationality, creativity, efficiency. Their observance, integrated with basic principles of higher education functioning, proclaimed by the State Legislation, foreign educational organizations and structures, will favor the quality increase of the competent physician-dentists' practical training.

\section{References}

1. Curaj, A., Pricopie, R., Deca, L. (Eds.) (2018). European Higher Education Area: The Impact of Past and Future Policies. Springer, 721. Available at: http://doi.org/10.1007/978-3-319-77407-7

2. Zakon Ukrainy «Pro osvitu» (2014). Uriadovyi kurier, 146, 7-18.

3. Guiding Principles for Higher Education. Available at: https://www.cois.org/colleges-and-universities/guiding-principlesfor-higher-education Last accessed: 20.08.20

4. Kulbashna, Ya. A. (2014). Formuvannia profesiinoi kompetentnosti maibutnikh fakhivtsiv iz stomatolohohii: teoretychni y metodychni osnovy. Kyiv: Kompas, 416.

5. MOZ Ukrainy opryliudnylo dlia hromadskoho obhovorennia Stratehiiu rozvytku medychnoi osvity. Available at: https://moz.gov.ua/article/reform-plan/moz-ukraini-opriljudnilo-dlja-gromadskogo-obgovorennja-strategiju-rozvitku-medichnoiosviti Last accessed: 17.08.2020

6. Abeshu, G., Urgessa, D., Sintayehu, A. (2020). Perceived features of practicum effectiveness and acquired professional competences among graduate class students in Dilla University. ScienceRise: Pedagogical Education, 4 (37), 4-8. doi: http://doi.org/10.15587/2519-4984.2020.206234 

20.08.2020

7. Turning Education Structure in Europe (2000). Available at: https://www.unideusto.org/tuningeu/ Last accessed:

8. Lukashchuk, M. M., Lukashchuk, I. M. (2018). Prakseolohichna spriamovanist formuvannia profesiinoi identychnosti maibutnikh medychnykh sester v protsesi navchannia khimiko-biolohichnykh dystsyplin v medychnomu koledzhi. Molodyi vchenyi, $2(2), 626-630$

9. Kotarbinskii, T. (1975). Traktat o khoroshei rabote. Moscow: Ekonomika, 271.

10. Polishchuk, V. A. (2014). Prakseolohichnyi pidkhid yak innovatsiina osnova vdoskonalennia profesiinoi pidhotovky maibutnikh sotsialnykh pratsivnykiv. Naukovyi visnyk Uzhhorodskoho natsionalnoho universytetu. Seriia: Pedahohika, 32, $148-150$.

11. Kulbashna, Y. A., Malanchuk, V. O., Nahirnyj, Y. P., Skrypnyk, I. L., Zakharova, V. O. (2020). A modern model of masters' in dentistry professional training. Medical Education, 1, 45-49. doi: http://doi.org/10.11603/me.2414-5998.2020.1.10992

12. Pro vyshchu osvitu (2014). Zakon Ukrainy No. 1556-VII. 01.07.2014. Available at: https://zakon.rada.gov.ua/laws/show/214519\#Text Last accessed: 20.07.20

13. Seven Principles for good Practice in Undergraduate Education. Available at: https://new.utc.edu/academicaffairs/walker-center-for-teaching-and-learning/online-resources/seven-principles-for-good-teaching

14. The Civil Rights for Higher Education (2019). Available at: http://civilrightsdocs.info/pdf/reports/Higher-Ed-CivilRights-Principles.pdf Last accessed: 20.08 .20

15. Nietzel, M. T. (2020). Three Core Principles For Higher Education As It Prepares For Its Pandemic-Uncertain Fall. Available at: https://www.forbes.com/sites/michaeltnietzel/2020/04/09/three-core-principles-as-higher-education-prepares-for-its-pandemic-uncertainfall/\#77c2cf1c348f Last accessed: 20.08.2020

16. Blanco, G., Hans de Wit (2020). The Response of International Higher Education Associations to COVID-19. International Higher Education, 102, 11-15.

Received date 04.08.2020

Accepted date 09.09.2020

Published date 30.09.2020

Yaroslava Kulbashna, Doctor of Pedagogical Sciences, PhD, Professor, Department of Surgical Dentistry and Oral and Maxillofacial Surgery, Bogomolets National Medical University, T. Shevchenko blvd., 13, Kyiv, Ukraine, 01601

E-mail: j.kulbashna@gmail.com

Iryna Skrypnyk, PhD, Associate Professor, Department of Orthodontics and Propedeutics of Prosthetic Dentistry, Bogomolets National Medical University, T. Shevchenko blvd., 13, Kyiv, Ukraine, 01601

E-mail: irynaskrypnyk@gmail.com 